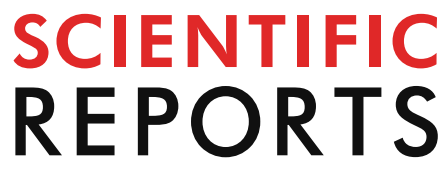

natureresearch

Check for updates

\title{
OPEN
}

\section{Author Correction: The LRRC8-mediated volume-regulated anion channel is altered in glaucoma}

\author{
Xavier Gasull ${ }^{D}$, Marta Castany, Aida Castellanos, Mikel Rezola, Alba Andrés-Bilbé, \\ Maria Isabel Canut, Raúl Estévez, Teresa Borrás \& Núria Comes $\mathbb{D}$
}

Correction to: Scientific Reports https://doi.org/10.1038/s41598-019-41524-3, published online 01 April 2019

The Acknowledgements section in this Article is incomplete.

"We are grateful to Dr. D.W. Stamer and his collaborators from Duke University Eye Center (Durham, N.C.) for their gift of human primary TM cells. The present work was supported by Ministerio de Economia y Competitividad and Instituto de Salud Carlos III of Spain FIS PI14/00141 (X.G.), FIS P17/00296 (X.G.), RETICs Oftared RD12/0034/0003 (X.G.), RD16/0008/0014 (X.G.), RD12/0034/0015 (M.C.), RD16/0008/0023 (M.C.), Generalitat de Catalunya 2014SGR1165 (X.G.), and National Eye Institute - NIH, EY-11906 (T.B.).”

should read:

"We are grateful to Dr. D.W. Stamer and his collaborators from Duke University Eye Center (Durham, N.C.) for their gift of human primary TM cells. The present work was supported by European Union, Fondo Europeo de Desarrollo Regional (FEDER), Ministerio de Economia y Competitividad and Instituto de Salud Carlos III of Spain FIS PI14/00141 (X.G.), FIS P17/00296 (X.G.), RETICs Oftared RD12/0034/0003 (X.G.), RD16/0008/0014 (X.G.), RD12/0034/0015 (M.C.), RD16/0008/0023 (M.C.), Generalitat de Catalunya 2014SGR1165 (X.G.), and National Eye Institute - NIH, EY-11906 (T.B.)."

(1) Open Access This article is licensed under a Creative Commons Attribution 4.0 International License, which permits use, sharing, adaptation, distribution and reproduction in any medium or format, as long as you give appropriate credit to the original author(s) and the source, provide a link to the Creative Commons license, and indicate if changes were made. The images or other third party material in this article are included in the article's Creative Commons license, unless indicated otherwise in a credit line to the material. If material is not included in the article's Creative Commons license and your intended use is not permitted by statutory regulation or exceeds the permitted use, you will need to obtain permission directly from the copyright holder. To view a copy of this license, visit http://creativecommons.org/licenses/by/4.0/.

(C) The Author(s) 2020 